Available Online : https://proceeding.researchsynergypress.com/index.php/cset/index

RSF Conference Series: Engineering and Technology

ISSN 2809-6843 (Online) | 2809-6878 (Print)

Volume 1 Number 1 (2021): 500-509

\title{
Adsorption of Iron (Fe) Heavy Metal in Acid Mine Drainage from Coal Mining
}

\author{
Edy Nursanto', Nurkhamim², Mycelia Paradise ${ }^{3}$ \\ 1, 2, 3 UPN "Veteran" Yogyakarta, Indonesia
}

\begin{abstract}
Adsorption is one of effective method to overcome acid mine drainage issue because of its economy and abundant availability of adsorbents. The research aimed to analyze the adsorption effectiveness and capacity of composite as the iron adsorbent in acid mine drainage. Composite consists of claystone from coal overburden, zeolite, and activated carbon from coconut shell. This study used experimental approaches in laboratory. Types of mineral contained in adsorbent materials (claystone, zeolite, and activated carbon) were: kaolinite, mordenite, and cristobalite. Composites were constructed with the following ratios: 50:25:25, 25:25:50, and 25:50:25 (Claystone[C] : Zeolite[Z] : Activated carbon[A]). The composite with a ratio of 25:25:50 had the greatest surface area of $62.44 \mathrm{~m} 2 / \mathrm{g}$, according to the results of the surface area analyzer test. Adsorption was performed in a batch system with a hot plate stirrer and composite mass of $2.5,5$, and 7.5 grams, for contact time variations of $30,60,90,120$, and 150 minutes. The adsorption test revealed that the composite was successful in increasing the $\mathrm{pH}$ of acid mine drainage to neutral (7.0) and lowering the Fe concentration to meet the quality standard. The best effectiveness of iron lowering was $99,35 \%$ with composite mass of 5 grams. However, the 2.5 grams composite mass is more efficient in terms of efficiency because it can lower the Fe concentration to $0.1484 \mathrm{mg} / \mathrm{l}$ with only 30 minutes contact time, ensuring that the Fe concentration fulfills the quality standard. The composite with a mass of 2.5 grams has the best adsorption capacity $(1,286 \mathrm{mg} / \mathrm{g})$.
\end{abstract}

Keywords: Adsorption, Capacity, Composite, Effectiveness

\section{INTRODUCTION}

This is an open access article under the CC-BY-NC license

Coal is a fossil fuel that is very important for human life, including as a source of energy for power plant, liquid fuel as a substitute for fuel oil, the main fuel in steel, aluminum and paper factories, etc. As a result, the coal mining sectors are critical to the country's economy. East Kalimantan, South Kalimantan, Central Kalimantan, South Sumatra, Jambi, and Sulawesi have the greatest coal reserves in Indonesia (esdm.go.id).

Overburden removal in mining processes exposes rocks containing sulfide minerals, which generate acid mine drainage when oxidized with free air and dissolved in water. Acid mine drainage (AMD) is water with a low $\mathrm{pH}$ value and high metal solubility (Indra, 2014). Acid mine drainage is difficult to avoid in open pit mines, particularly in those with a high percentage of PAF (Potential Acid Forming) rock. It can pollute the environment, corrode mining equipment, and degrade water quality. Furthermore it will affect soil fertility, interfere the life of plants and animals, and affect human health such as cancer, kidney failure, digestive disorders, and others due to the accumulation of heavy metals in human body. Iron (Fe) is the most common heavy metal in acid mine drainage. Total iron maximum in acid mine drainage of coal mining based on the local quality standard is $7 \mathrm{mg} / \mathrm{l}$ (KEPMEN LH No.113 Tahun 2003).

Heavy metals can be absorbed using waste-derived adsorbents. Indonesia is a tropical country where the availability of coconut tree is abundant. Coconut shell can be activated and used as adsorbents. Activated carbon from coconut shell has greater micropores and lower ash content than activated carbon from other materials such as rice husks, wood, bamboo, bagasse, and peanut shells (Pambayun dkk., 2013).

Claystone (clay) is a hydrousaluminum silicate $(\mathrm{Al} 2 \mathrm{O} 3.2 \mathrm{SiO} 2.2 \mathrm{H} 2 \mathrm{O}$ ) thatcan be used to remove heavy metals from wastewater due to its high sorption capacity on some heavy metals (Musso Claystone (clay) is a hydrous aluminum silicate $\left(\mathrm{Al}_{2} \mathrm{O}_{3} .2 \mathrm{SiO}_{2} .2 \mathrm{H}_{2} \mathrm{O}\right)$ that can be used to remove heavy metals from wastewater due to its high sorption capacity on some heavy metals (Musso et al., 2014). Claystone from coal overburden in mining area is abundant and has not been used optimally. 


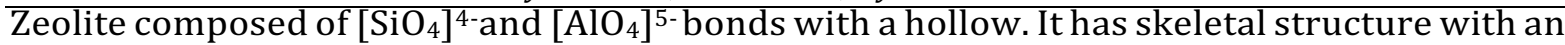
empty space populated by free water molecules. Therefore it can be applied to absorb heavy metals (Catri, 2016).

There are many studies about the use of claystone, zeolite, or activated carbon from coconut shell, but the study about the use of these three materials mixed into a composite to absorb heavy metals has never been done before. Therefore, this study applied claystone, activated carbon from coconut shell, and zeolite as a composite to absorb iron (Fe) from acid mine drainage in coal mining.

The aims of this study were to analyze the characteristics of composites as adsorbent in the adsorption of iron (Fe) from the sample of acid mine drainage and to analyze the adsorption capacity.

\section{LITERATURE REVIEW}

Acid Mine Water (AAT) known as Acid Mine Drainage or Acid Rock Drainage (AMD or ARD) is acidic water (high acidity level and is often characterized by a low $\mathrm{pH}$ value below $\mathrm{pH}=6$ as a result of the oxidation of sulfide minerals exposed to the air and the presence of water. Water pollution caused by acid mine water can be recognized by the presence of iron hydroxide deposits that are yellow to reddish at the bottom of streams or puddles. These deposits are formed due to the oxidation of dissolved iron $\left(\mathrm{Fe}^{2+}\right)$ in acid water mine by oxygen.

Excavation and stockpiling activities result in the exposed rock so that it allows contact with air and water. Runoff water that comes from rain, flows and contacts the mining pit walls. The results of weathering of rocks or chemical reactions between air and sulfide minerals when exposed to rainwater or groundwater seepage can result in changes in the quality of the run off or groundwater.

\section{AAT Forming Process}

The reaction for the formation of acid mine water required the presence of three components, namely:

$$
\begin{aligned}
& \text { Sulfur }(\mathrm{S}) \\
& \text { Water }\left(\mathrm{H}_{2} \mathrm{O}\right) \\
& \text { Oxygen }\left(\mathrm{O}_{2}\right)
\end{aligned}
$$

Based on the presence of sulfur minerals in rocks, it is very easy to oxidize, so it is necessary to know the types of sulfur in the form of sulfide minerals as follows:

Pyrite (FeS), Chalcocite (Cu2S), Covellite (CuS),Molybdenite (MoS2), Chalcopyrite (CuFeS2), Galena (PbS), Sphalerite (ZnS), Arsenopyrite (FeAs), Marcasite (FeS2), Pyrrhotite (FeS)

Water coming from coal mines will have a characteristic red-brown, yellow, and sometimes white color. The water can be acidic or basic depending on the level of concentration of sulfate $\left(\mathrm{SO}_{4}{ }^{-}\right)$, iron $(\mathrm{Fe})$, manganese $(\mathrm{Mn})$, and elements such as calcium, sodium, potassium, and magnesium. Based on all these sulfide minerals, pyrite is the most dominant sulfide mineral present in the rock/ore. The reaction between the mineral pyrite, oxygen, and water will form sulfuric acid and iron hydroxide precipitate. The yellowish color that settles at the bottom of the mining channel or on the walls of the sludge settling pond is a visual picture of iron hydroxide deposits or called yellow boy. In general, the chemical equation can be seen in the process of forming acid mine drainage in equation below.

$$
\begin{aligned}
& 4 \mathrm{FeS}_{2}+15 \mathrm{O}_{2}+14 \mathrm{H}_{2} \mathrm{O} \rightarrow 4 \mathrm{Fe}\left(\mathrm{OH}_{3}\right)+8 \mathrm{H}_{2} \mathrm{SO}_{4} \\
& \text { (Pyrite + Oxygen + Water } \rightarrow \text { Ferric Hydroxide (Yellow boy) + Sulfiric Acid) }
\end{aligned}
$$

Watzlaf et al. (2004) stated that the oxidation of pyrite (FeS2) will form ferrous ions $\left(\mathrm{Fe}^{2+}\right)$, sulfate, and some protons forming acidity, so that the environmental conditions become acidic. Stumm and Morgan (1981) describe the oxidation reaction of pyrite $\left(\mathrm{FeS}_{2}\right)$ in equations as follows:

Reaction I: $2 \mathrm{FeS}_{2}+7 \mathrm{O}_{2}+2 \mathrm{H}_{2} \mathrm{O} \rightarrow 2 \mathrm{Fe}^{2+}+4 \mathrm{SO}_{4}^{2-}+4 \mathrm{H}^{+}$ 
Reaction II: $\mathrm{Fe}^{2+}+1 / 4 \mathrm{O}_{2}+\mathrm{H}^{+} \rightarrow \mathrm{Fe}^{3+}+1 / 2 \mathrm{H}_{2} \mathrm{O}$

Ferrous Iron + Oxygen + Acidity $\rightarrow$ Ferric Iron + Water

(ferrous iron will be oxidized to ferric iron)

Reaction III: $\mathrm{Fe}^{3+}+3 \mathrm{H}_{2} \mathrm{O} \rightarrow \mathrm{Fe}(\mathrm{OH})+3 \mathrm{H}^{+}$

Ferric Iron + Water $\rightarrow$ Ferric Hydroxide (Yellow Boy) + Acidity

(ferrous iron can be hydrolyzed to form ferric hydroxide and acid)

Reaction IV: $\mathrm{FeS}_{2}+14 \mathrm{Fe}^{3+}+8 \mathrm{H}_{2} \mathrm{O} \rightarrow 15 \mathrm{Fe}^{2+}+2 \mathrm{SO}_{4}{ }^{2-}+16 \mathrm{H}^{+}$

Pyrite + Ferric Iron + Water $\rightarrow$ Ferrous Iron + Sulfate + Acidity

(The ferrous iron reacts directly with pyrite, and acts as a catalyst causing very large ferrous iron, sulfates, and acids)

The equation above shows that $\mathrm{H}^{+}$ions can be liberated from pyrite oxidation in the first reaction, hydrolysis of $\mathrm{Fe}^{3+}$ (in the third reaction) or through the reaction of $\mathrm{Fe}^{3+}$ with pyrite (in the fourth reaction). Fe-oxidizing bacteria, namely thiobacillus, accelerated the $\mathrm{Fe}^{2+}$ oxidation reaction to $\mathrm{Fe}^{3+}$ in the second reaction. Iron metal $(\mathrm{Fe})$ will accumulate in both soil and water. Besides $\mathrm{Fe}, \mathrm{AAT}$ also found other heavy metals, including $\mathrm{Mn}, \mathrm{Zn}, \mathrm{Cu}, \mathrm{Ni}, \mathrm{Pb}$, and $\mathrm{Cd}$.

Important factors that influence the formation of AAT in a place are:

1. Concentration, distribution, mineralogyand, physical form of the sulfideminerals present,

2. The presence of oxygen in the air, including in this case the intake from the atmosphere through advection and diffusion mechanisms,

3. The chemical composition and amount of water present, temperature and microbiology.

Taking into account these factors, it can be said that the formation of AAT is highly dependent on the conditions in which it is formed. Differences in one of the factors mentioned above lead to different formation processes and results. Therefore, related to these matters, the characteristics of AAT in one mining area will be different from mining in other areas.

Heavy metals are chemical elements with a density greater than $5 \mathrm{~g} / \mathrm{cm}$, have a high affinity and usually atomic numbers 22 to 92 , from the period 4 to 7 .

Heavy metals are still a metal group with the same criteria as other metals. The difference lies in the effect produced when these heavy metals bind to and or enter living organisms. Unlike ordinary metals, heavy metals cause special effects on live things.

It can be said that all heavy metals can be toxic materials that can poison the bodies of living things. For example, metallic mercury ( $\mathrm{Hg})$, cadmium (Cd), lead (Pb), manganese (Mn), iron (Fe). Although all heavy metals can cause poisoning to living things, some of these heavy metals are still needed by living things. Because they are needed in the body, they are called essential metals, these essential metals are copper $(\mathrm{Cu})$, zinc $(\mathrm{Zn})$, iron $(\mathrm{Fe})$, magnesium $(\mathrm{Mg})$. The explanation of iron (Fe) and manganese $(\mathrm{Mn})$ is as follows:

a. Iron (Fe)

Metal Iron $\left(\mathrm{Fe}^{+}\right)$is a transition metal and has an atomic number of 26 . He has an atomic weight of $55.845 \mathrm{~g} / \mathrm{ml}$, a melting point of $1.538^{\circ} \mathrm{C}$, and a boiling point of $2.861^{\circ} \mathrm{C}$ ranks among the top ten elements on earth. Metal Iron $\left(\mathrm{Fe}^{+}\right)$is found in the form of hematite in the earth's core. Iron metal $\left(\mathrm{Fe}^{+}\right)$can hardly be found as a free element. It is estimated that in the earth's crust the $\left(\mathrm{Fe}^{+}\right)$content is $5.63 \times 104 \mathrm{mg} / \mathrm{kg}$ while the content in the sea is $2 \mathrm{x}$ $10-3 \mathrm{mg} / \mathrm{L}$.

Iron in groundwater is usually in the form of $\left(\mathrm{Fe}^{2+}\right)$ and $\left(\mathrm{Fe}^{3+}\right)$ dissolved. Dissolved ferrous $(\mathrm{Fe} 2+)$ can combine with organic matter and form complex compounds that are difficult to remove by ordinary aeration.

The characteristics of high levels of iron in the soil are as follows:

1 . There is a layer like oil on the surface of the water 
In reducing ferrous metal pollution, phytoremediation technology can be used, increasing the $\mathrm{pH}$ of the solution, active sand filter, bio removal microorganisms, and oxidation using $\mathrm{H}_{2} \mathrm{O}_{2}$ as an oxidizing agent.

\section{RESEARCH METHODOLOGY}

This research was conducted on a laboratory scale by utilizing claystone from coal overburden, zeolite, and activated carbon from coconut shell, mixed into a composite as an adsorbent of Fe metals from the sample of acid mine drainage through a batch system adsorption. Adsorption was carried out on a various of parameters, in order to obtain optimal conditions for neutralizing acid mine drainage, both $\mathrm{pH}$ and iron (Fe) concentration.

\section{Literature review}

Literature study was conducted to collect information related to this research. Literature study was carried out by studying research results, scientific journals, literatures, and books related to the issue solved by the researcher.

2. Method of data collection

Data in this research include primary and secondary data. Primary data were diffraction pattern of claystone, activated claystone, activated zeolite, coconut shell carbon, activated carbon from coconut shell, iron concentration and $\mathrm{pH}$ of acid mine drainage before and after adsorption. Secondary data was diffraction pattern of zeolite Klaten.

3. Sampling

Purposive sampling was utilized in this study. 5 liters sample of acid mine drainage was obtained from thepitsump.Claystonesamplefrom PT.Indominco'swestblockcoal overburden. Coconutshellsfrom Bontang. Klaten zeolite from Central Java.

4. Laboratory Testing

The claystone, zeolite, and coconut shell samples were physically and chemically activated after sampling to increase their ability to absorb Fe. Physically activation was obtained by heating the materials in certain temperature $\left(700^{\circ} \mathrm{C}\right.$ in 30 minutes for claystone, $80^{\circ} \mathrm{C}$ in 24 hours for zeolite, and $110^{\circ} \mathrm{C}$ in 3 hours for coconut shell carbon). Fe. Chemically activation was obtained by soaking the materials into chemical solutions $(3 \mathrm{M} \mathrm{NaOH}$ for claystone, $3 \mathrm{M} \mathrm{HCl}$ for zeolite, and $4 \mathrm{M} \mathrm{HCl}$ for coconut shell carbon). The materials were analyzed by X-Ray Diffraction (XRD) to determine their type of minerals. The samples of acid mine drainage were analyzed refers to the water quality testing method based on the Indonesian National Standard (SNI) using Atomic Absorption Spectroscopy (AAS) to determine its iron concentration and $\mathrm{pH}$ meter to determine its $\mathrm{pH}$. Composite made by mixing the activated clay, zeolit, and carbon with certain ratios ( 50:25:25;25:25:50 ; 25:50:25). Adsorption was performed by placing $250 \mathrm{ml}$ of AMD water sample in a beaker glass with a composite $(2.5 \mathrm{~g})$. By adjusting the rotating speed $(300 \mathrm{rpm})$ and temperature $\left(25^{\circ} \mathrm{C}\right)$, the beaker glass was then placed on a hot plate stirer to mix the AMD and composite in a certain contact times $(30,60,90,120$, and 150 minutes). When the adsorption was complete, the solution was filtered through filter paper and the $\mathrm{pH}$ was measured. Next, AAS testing was used to evaluate the remaining concentration of iron in the solution after adsorption. The amount of iron and manganese ion adsorbed per composite mass unit (adsorption capacity) (mg/g) and adsorption effectiveness (\%) were estimated using the following formulas.

\footnotetext{
Adsorption capacity $=$ (initial concentration - equilbrium concentration $)$.volume of solution mass of composite

Adsorption effectiveness $=\frac{(\text { initial concentration-equilibrium concentration })}{\text { initial concentration }} \times 100 \%$
} 


\section{DISCUSSION}

\section{Acid Mine Drainage Before Adsorption}

Based on the result of $\mathrm{pH}$ meter, the $\mathrm{pH}$ of acid mine drainage from pit sump PT. Indominco was 2.6. the iron concentration of acid mine drainage was $13,006 \mathrm{mg} / \mathrm{l}$ according to the result of Atomic Absorption Spectroscopy in the laboratory of Balai Teknis Kesehatan Lingkungan Yogyakarta.

\section{X-Ray Diffraction (XRD) Testing Result}

The composite-forming material was analyzed by X-Ray Diffraction (XRD) to determine mineral content in the materials of claystone, zeolite, and coconut shell carbon both before and after activation. However, for the Klaten zeolite XRD data before activation was taken by the XRD test conducted by Pohan et al, 2016 as secondary data. The results of the XRD test are qualitative data based on matching results of intensity and angle of $2 \theta$ using Match software. This software already has a certain database for the diffraction pattern of each material being compared and matched with the material beingtested.

\section{Claystone}

The diffraction pattern of claystone before and after activation can be seen in Figures 1 and 2.

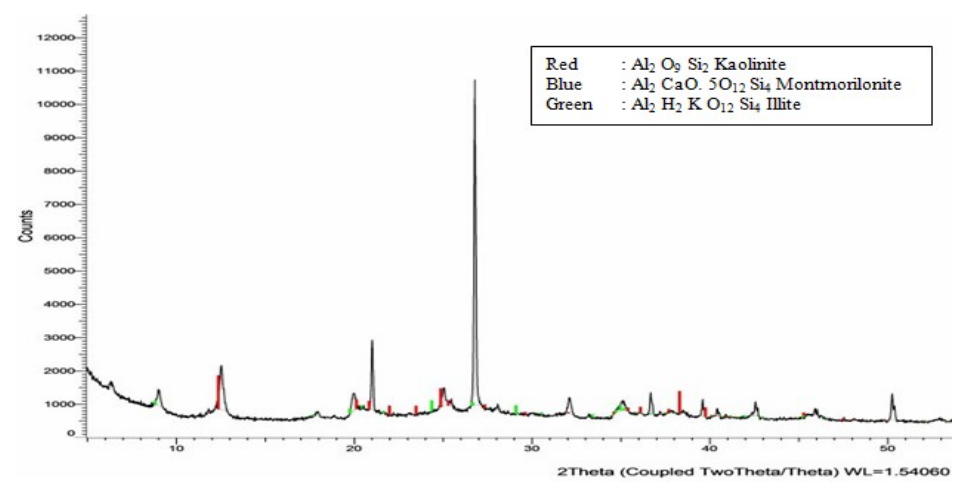

Figure 1. Diffractogram pattern of claystone

The diffraction peak (Fig.1) at $2 \theta$ showed that the claystone from PT. Indominco Mandiri's West block coal overburden material contains mostly kaolinite, illite, and montmorillonite. It was showed by $2 \theta$

$=12,2^{\circ} ; 20,8^{\circ} ; 22^{\circ} ; 23,5^{\circ} ; 25^{\circ} ; 25,5^{\circ} ; 27,3^{\circ} ; 29,5^{\circ} ; 32^{\circ} ; 34,8^{\circ} ; 35,8^{\circ} ; 37,5^{\circ} ; 38,2^{\circ} ; 39,8^{\circ} ; 41^{\circ}$ ; $45,2^{\circ} ; 47,5^{\circ} ; 48^{\circ} ; 49,8^{\circ} ; 5^{\circ} ; 57,5^{\circ} ; 60,2^{\circ} ; 62,5^{\circ} ; 69,5^{\circ} ; 72,8^{\circ} ; 73,8^{\circ} ; 75^{\circ}$ (kaolinite), $20,2^{\circ}$; $20,4^{\circ}$;

$22^{\circ} ; 23,5^{\circ} ; 25^{\circ} ; 25,5^{\circ} ; 27^{\circ} ; 29,5^{\circ} ; 35,5^{\circ} ; 36,5^{\circ} ; 40^{\circ} ; 45,5^{\circ} ; 47,5^{\circ} ; 55^{\circ} ; 57,5^{\circ} ; 60,5^{\circ} ; 63^{\circ} ; 69,5^{\circ}$

$74^{\circ} ; 7^{\circ}$ (illite), $12^{\circ} ; 20,8^{\circ} ; 30,9^{\circ} ; 36,5^{\circ} ; 39^{\circ} ; 42,3^{\circ} ; 46^{\circ} ; 47,2^{\circ} ; 48,5^{\circ} ; 50,8^{\circ} ; 55,5^{\circ}$; $59,8^{\circ}$

(montmorilonite). 


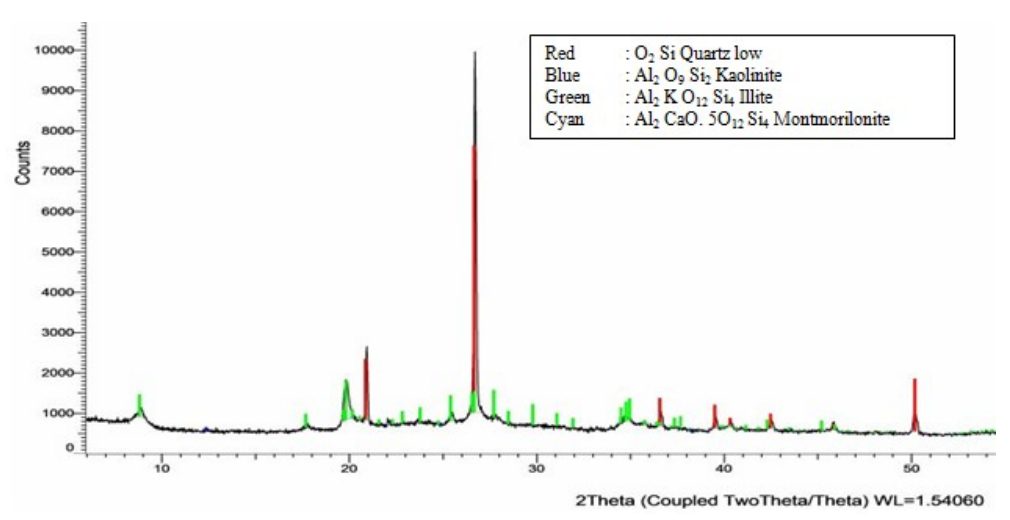

Figure 2. Diffractogram pattern of activated claystone

New peaks arised in diffractogram pattern of activated claystone (Fig. 2) at $2 \theta=21^{\circ} ; 26,5^{\circ}$; $34,5^{\circ} ; 39,5^{\circ} ; 40,3^{\circ} ; 42^{\circ} ; 46^{\circ} ; 50^{\circ} ; 55,5^{\circ} ; 56,2^{\circ} ; 60^{\circ} ; 64^{\circ} ; 66^{\circ} ; 68,8^{\circ} ; 69,3^{\circ} ; 73,6^{\circ} ; 75,8^{\circ} ; 77,8^{\circ}$ (Quartz).

The increasing intensity was indicated by the diffractogram of activated claystone. The more mineral crystals in claystone, the higher its diffraction intensity.

\section{Zeolite}

The diffraction pattern of zeolite before and after activation can be seen in Figure 3 and 4 .

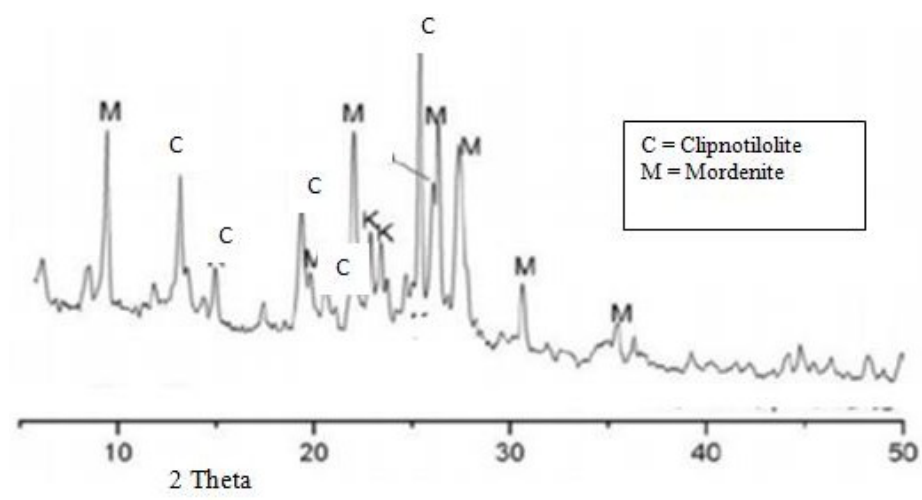

Figure 3. Diffractogram pattern of zeolite

Diffractogram of zeolite Klaten (Fig 3) at $2 \theta=6.808 ; 5,976 ; 4,625 ; 4.353 ; 3,921 ; 3,834 ; 3,535$ and 3,439 (clinoptilolite) showed high intensity peaks. Besides that, there were fairly high intensity at $2 \theta=9.516 ; 4,516 ; 4,076 ; 3,404 ; 3,269 ; 2,935$ and 2,549 (mordenite).

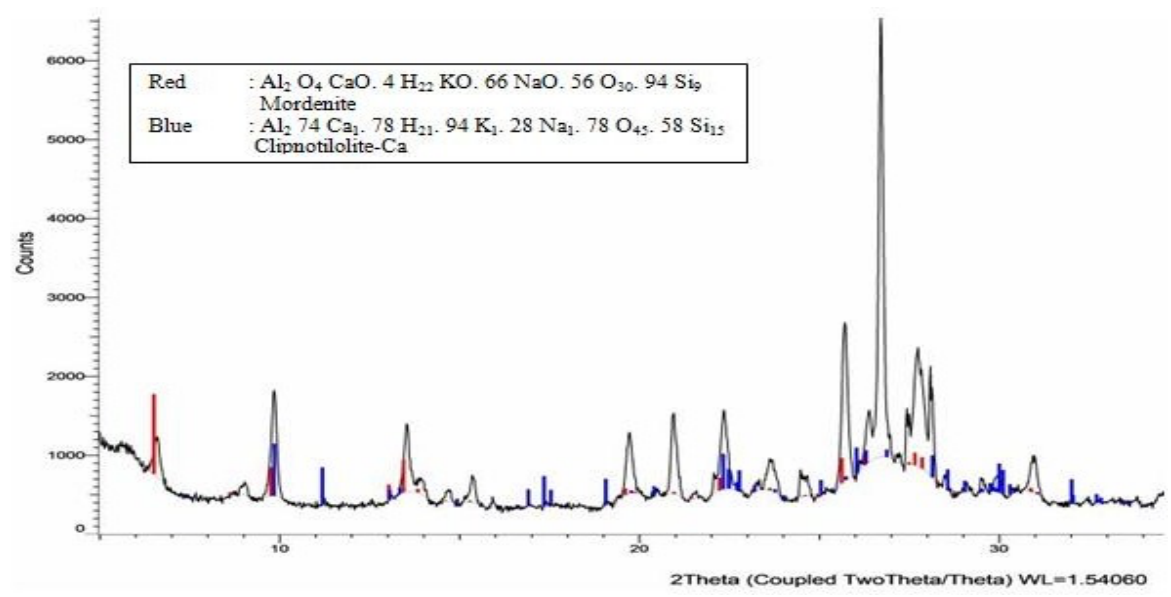

Figure 4. Diffractogram pattern of activated zeolite 
According to diffractogram pattern of activated zeolite (Fig.4), there wasincreasing intensity because activation may clear impurities from zeolite, resulting higher crystallinity.

\section{Coconut shell carbon}

According to diffractogram pattern of coconut shell carbon (Fig.5), the peaks tend to spread irregularly, indicating that the crystal structure of Bontang coconut shell carbon was amorphous.

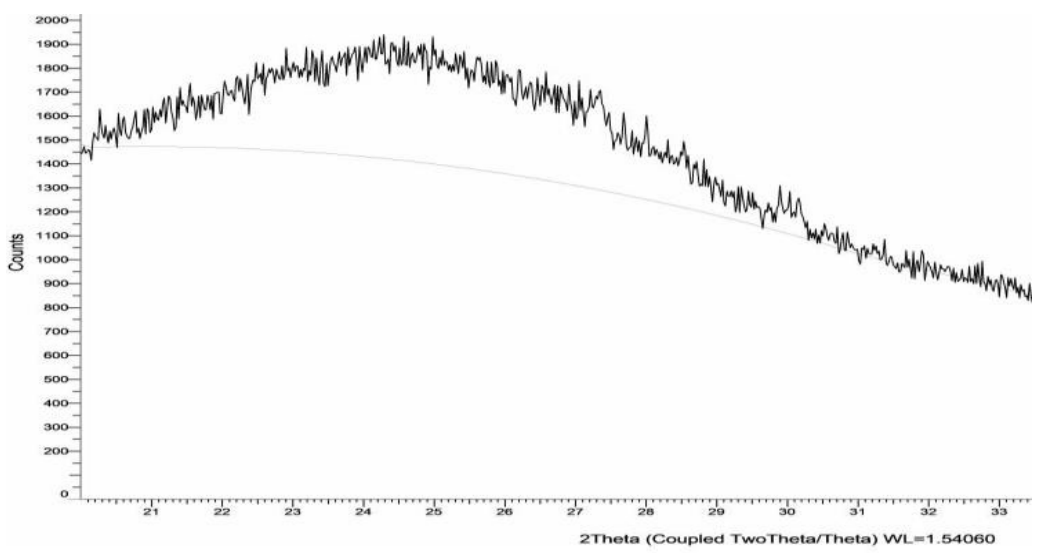

Figure 5. Diffractogram pattern of coconut shell carbon

When coconut shell carbon was activated, there were new peaks on its diffractogram pattern (Fig.6): $2 \theta=12^{\circ} ; 21,6^{\circ} ; 22^{\circ} ; 22,5^{\circ} ; 23,4^{\circ} ; 24,1^{\circ} ; 24,7^{\circ} ; 2^{\circ} ; 25,2^{\circ} ; 26,2^{\circ} ; 26,7^{\circ} ; 27,8^{\circ} ; 28,1^{\circ}$; $28,2^{\circ} ; 29,4^{\circ}$;

$29,5^{\circ} ; 30^{\circ} ; 30,4^{\circ} ; 30,6^{\circ} ; 31,3^{\circ} ; 33,2^{\circ} ; 33,4^{\circ} ; 33,6^{\circ}$ (manganoeudialyte), $2 \theta=25^{\circ} ; 29,1^{\circ} ; 29,3^{\circ}$; $31,6^{\circ}$ ; $34^{\circ} ; 34,2^{\circ} ; 35^{\circ} ; 35,8^{\circ}$ (fayalite) , $2 \theta=22,2^{\circ} ; 28,4^{\circ} ; 31,4^{\circ} ; 36,1^{\circ}$ (cristobalite)

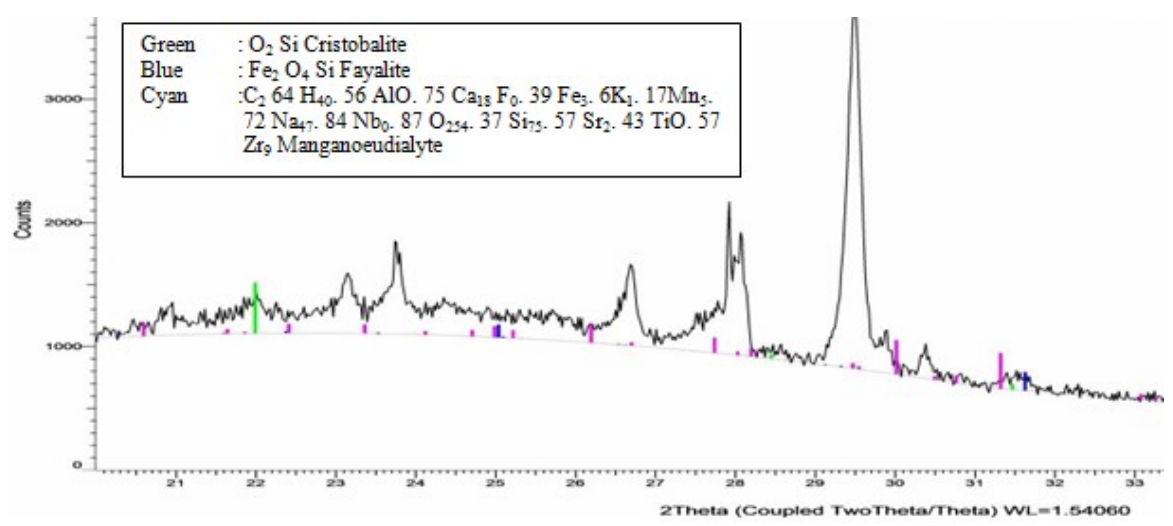

Figure 6. Diffractogram pattern of activated carbon

\section{Adsorption Result}

Due to its highest surface area $\left(62.4423 \mathrm{~m}^{2} / \mathrm{g}\right)$, the adsorbent used to adsorp iron from acid mine drainage in this study was composite with 25:25:50 ratio. The other ratios had lower surface area than composite 25:25:50 $\left(37.9 \mathrm{~m}^{2} / \mathrm{g}\right.$ for $50: 25: 25$ ratio and $32.3 \mathrm{~m}^{2} / \mathrm{g}$ for 25:50:25 ratio).

pH of acid mine drainage after adsorption

The $\mathrm{pH}$ of the acid mine drainage was raised through adsorption (Fig.7) 


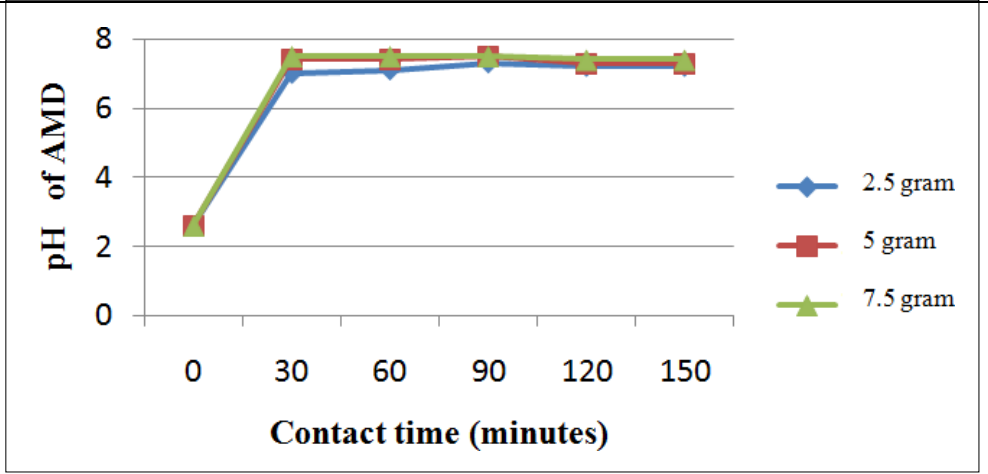

Figure 7. pH of acid mine drainage after adsorption

A significant increasing in $\mathrm{pH}$ levels showed by 2.5 grams of composite at 30 minutes of contact time, from the initial $\mathrm{pH}$ of 2.6 to 7.0. Along with the addition of the contact time, the $\mathrm{pH}$ of the acid mine drainage also increased to 7.1 (at 60 minutes of contact time) and increased again to 7.3 when the contact time was 90 minutes. However, the pH decreased slightly to 7.2 at 120 and 150 minutes of contact time. The average of $\mathrm{pH}$ increasing was $63.68 \%$, from the initial $\mathrm{pH}$ of 2.6 to 7.2. In composite mass of 5 grams, the effectiveness of pH increasing were $64.86 \%$ for 30 and 60 minutes , $65.33 \%$ for 90 minutes, and $64.38 \%$ for 120 and 150 minutes. The average of $\mathrm{pH}$ increasing was $64.76 \%$, from the initial $\mathrm{pH}$ of 2.6 to 7.5 . In composite mass of 7.5 grams, the effectiveness of pH increasing at 30 to 90 minutes of contact time were $65.33 \%, 64.86 \%$ for 120 and 150 minutes. The average of $\mathrm{pH}$ increasing was $65.14 \%$, from the initial $\mathrm{pH}$ of 2.6 to 7.5. Among three variations of composite mass, the most effective $\mathrm{pH}$ changing was composite mass of 7.5 grams with average effectiveness of $65.14 \%$. However, in terms of efficiency, the composite mass of 2.5 grams was more efficient in increasing the $\mathrm{pH}$ of AMD from 2.6 to 7.0 to meet the quality standard.

The $\mathrm{pH}$ increasing is related to the composite material as an adsorbent. One of the composite materials was claystone from coal overburden which contains kaolinite and montmorillonite. Kaolinite and montmorillonite have a high cation exchange capacity (kaolinite 2-16 meq/100 g and montmorillonite 60-100 meq/100 g) (Mukhlis, 2004 in Hafiz et al, 2015). Furthermore, in adsorption, the stirring speed can speed up the solubility process and the equilibrium of $\mathrm{H}^{+}$and $\mathrm{OH}^{-}$ions in AMD.

\section{Adsorption effectiveness}

Adsorption effectiveness can be seen at Figure 8.

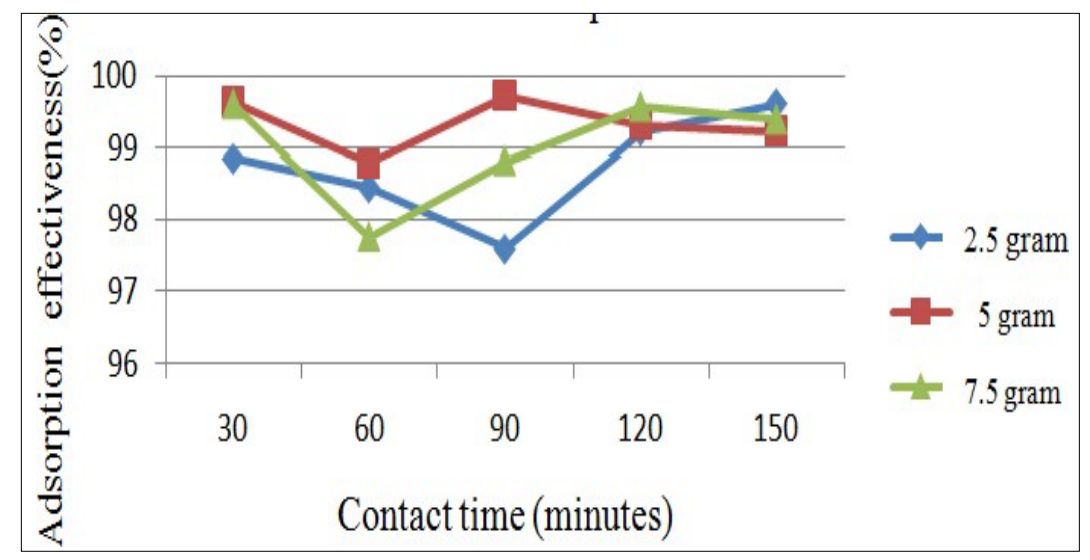

Figure 8. Adsorption effectiveness

The effectiveness of decreasing iron concentration with 2.5 grams of composite mass were $98.86 \%$ for 30 minutes, $98.46 \%$ for 60 minutes, $97.61 \%$ for 90 minutes, $99.24 \%$ and $99.61 \%$. for 120 and 
minutes 150 minutes. The average effectiveness was $98.76 \%$, from initial concentration of $13.006 \mathrm{mg} / \mathrm{l}$ to $0.051 \mathrm{mg} / \mathrm{l}$. In 5 grams of composite mass, its effectiveness were $99.65 \%$ for 30 minutes, $98.79 \%$ for 60 minutes, $99.73 \%$ for 90 minutes, $99.32 \%$ and $99.24 \%$ for 120 and 150 minutes. The average effectiveness was $99.35 \%$, from the initial concentration of $13.006 \mathrm{mg} / \mathrm{l}$ to $0.035 \mathrm{mg} / \mathrm{l}$. Meanwhile, when adsorption was carried out with composite mass of 7.5 grams, the average effectiveness was not much different from the effectiveness of 5 gram composite mass. The average effectiveness was $99.04 \%$, from the initial concentration of $13.006 \mathrm{mg} / \mathrm{l}$ to $0.051 \mathrm{mg} / \mathrm{l}$.

From the results obtained, it was proven that the composite was very effective in decreasing iron concentration in AMD. The best effectiveness of iron decreasing was $99.35 \%$ with composite mass of 5 grams. However, in terms of efficiency, the 2.5 gram composite mass was more efficient decreasing iron concentration to meet the local quality standard.

\section{Adsorption capacity}

Adsorption capacity can be seen at Figure 9.

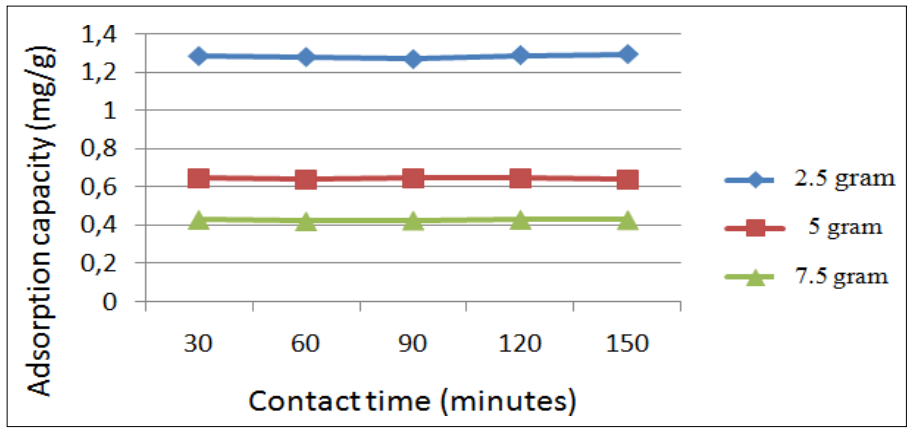

Figure 9. Adsorption capacity

The adsorption capacity of the composite with a mass of 2.5 grams was the best adsorption capacity. The adsorption capacity was $1.286 \mathrm{mg} / \mathrm{g}$ for 30 minutes of contact time, which means that each gram of composite was able to absorb $1.286 \mathrm{mg}$ of iron metal. The increasing of contact time up to 150 minutes did not result in substantial changes in adsorption capacity. It was because the adsorbent had reached saturation on 30 minutes of contact time, so the adsorption was no longer effective with the additional contact time. Based on the calculation of the adsorption capacity, the more mass of the composite does not causing better adsorption capacity. The adsorption capacity of the composite mass of 2.5 grams was actually better than the composite mass of 5 and 7.5 grams. In terms of effectiveness,

2.5 gram composite mass is the best choice because of its large adsorption capacity even with a small composite mass.

\section{CONCLUSSION}

The results of XRD analysis showed that claystone from West Block coal overburden of PT. Indominco Mandiri contains kaolinite, zeolite Klaten contains mordenite, and coconut shell from Bontang contains manganoeudialyte. Composite composed of $25 \%$ claystone, $25 \%$ zeolite and $50 \%$ activated carbon is the best composite with large surface area.

The adsorption effectiveness and capacity of the composites are as follows:

Composite with a mass of 2.5 grams is the most efficient and effective composite to increase $\mathrm{pH}$ and decrease iron (Fe) concentration to meet the local quality standard

The adsorption effectiveness of iron (Fe) is $99 \%$

The adsorption capacity of iron (Fe) is 1,286

$\mathrm{mg} / \mathrm{g}$

\section{REFERENCE}

Balintova, M., Holub, M., Stevulova, N., Cigasova, J., \& Tesarcikova, M. 2014. Sorption in acidic environment-biosorbents in comparison with commercial adsorbens. Chemical Enginering, 39. 
Catri, C. R. 2016. The Effectiveness of Natural Zeolite as Metal Absorbent Copper (II) in Pool Water With Coloumn Adsorption Method.. Jurnal Penelitian Saintek, 21(2), 87-95.

Gobel, A. P. 2018. Efektifitas pemanfaatan fly ash batubara sebagai adsorben dalam menetralisir air asam tambang pada settling pond penambangan banko PT. Bukit Asam (Persero), Tbk. Jurnal Mineral, Energi, dan Lingkungan, 2(1), 1-11.

Kerndorff, H., dan Schnitzer, M., 1980, "Sorption of Metals on Humic Acid", Geochim. Cosmochim. Acta, $44: 1577-1581$.

Li, W., Peng, J., Zhang, L., Yang, K., Xia, H., Zhang, S., \& Guo, S. H. 2009. Preparation of activated carbon from coconut shell chars in pilot-scale microwave heating equipment at $60 \mathrm{~kW}$. Waste management, 29(2), 756-760.

Mukarrom, F., Karsidi, R., Gravitiani, E., Astuti, F., \& Maharditya, W. 2020. The assessment of claystone, quartz and coconut shell charcoal for adsorbing heavy metals ions in acid mine drainage. In IOP Conference Series: Materials Science and Engineering (Vol. 858, No. 1, p. 012040). IOP Publishing.

Musso, T. B., Parolo, M. E., Pettinari, G., \& Francisca, F. M. 2014. Cu (II) and Zn (II) adsorption capacity of three different clay liner materials. Journal of environmental management, 146, 50-58.

Nwosu, F. O., Ajala, O. J., Owoyemi, R. M., \& Raheem, B. G. 2018. Preparation and characterization of adsorbents derived from bentonite and kaolin clays. Applied Water Science, 8(7), 195

Patterer S., Bavasso I., Sambeth J., Medici F., 2017, Cadmium removal from acqueous solution by adsorption on spent coffee grounds, Chemical Engineering Transactions, 60, 157-162 DOI: $10.3303 /$ CET1760027

Pranoto, Martini, T., Astuti, F., \& Maharditya, W. 2020. Test The Effectiveness and Characterization of Quartz Sand/Coconut Shell Charcoal Composite as Adsorbent of Manganese Heavy Metal. IOP Conference Series: Materials Science and Engineering. 858. 012041. 10.1088/1757899X/858/1/012041.

Rahmawati, Atik \& Santosa, Sri. 2013. Studi Adsorpsi Logam Pb(II) Dan Cd(II) Pada Asam Humat Dalam Medium Air. ALCHEMY. 10.18860/al.v0i0.2296.

Roca, Y. B., \& Fuentes, W. S. 2019. Use of Nanoclay as an Adsorbent to Remove Cu (ii) from Acid Mine Drainage (amd). Chemical Engineering Transactions, 73, 241-246.

Tan, I. A. W., Abdullah, M. O., Lim, L. L. P., \& Yeo, T. H. C. 2017. Surface modification and characterization of coconut shell-based activated carbon subjected to acidic and alkaline treatments. Journal of Applied Science \& Process Engineering, 4(2), 186-194. 